Cumhuriyet International Journal of Education-CIJE

e-ISSN: 2147-1606

Vol 5(4), 2016, 89 - 102

\title{
Prospective Teachers' Perceptions about the Importance of History of Turkish Education
}

\author{
Ramazan ALABAŞ
}

\section{Summary}

\section{INTRODUCTION}

The History of Turkish Education course is a course helping students see the current educational developments in terms of historical continuity in addition to bringing students in having the ability to comment on the perception and the practice of education, and the ability to think historically about different subjects of education. By means of this course, taught in education faculties training teachers, the comprehension of education in different periods of history of Turkish education are dealt with various aspects. In order to get the desired productivity of the course in university degree, it is necessary to develop continuously the content, the learning and the teaching process and the extent of evaluation in addition to the aims of the course. Hence, the aim of this study is to elicit prospective teachers' perceptions about the importance of History of Turkish Education course.

\section{METHOD}

This study used qualitative methodology and the participants of the study were 77 prospective teachers, determined by using purposeful sampling strategy. There were two different data collection tools of the study: Structured interview and open-ended question form. Structured interview was used to take prospective teachers' opinions about the identification of the course, learning situation and the importance of the course's subjects. Open-ended question form was used to take prospective teachers' opinions about which subject is important for them within the content of the course and why it is important. The collected data were analyzed with descriptive and content analysis.

\section{FINDINGS}

The findings got in the research are evaluated under three headlines; the perception which the prospective teachers have about the Turkish Education History, how important the prospective teachers find the History of Turkish Education Course to be in undergraduate education programs, and the topics they see as important in History of Turkish Education course.

The events happened in education at different periods of Turkish history, course type, science field and concept are in the high level while education practices, learning from the past, the means of cultural transfer and having knowledge about education are in low level in terms of the perception which the prospective teachers have about the History of Turkish Education.

Another finding got in the research is that almost all the prospective teachers attending to the research see the History of Turkish Education course to be in the undergraduate education programs they follow as important. In the reasons why the participants find the course as important, "having knowledge about the education in the past, learning from the past experiences about education and conceptualizing the point we have reached in education" are on the top level as expressions.

Another finding got in the research is that the subjects which the prospective teachers see as the most important ones in History of Turkish Education are the place of the scientists 
or thinkers providing something to the education in History of Turkish Education, the place of various dimensions of teacher training in Turkish Education History, and the place of education institutions or schools in History of Turkish Education.

The participants give less importance to the subjects about the history of the firsts in education and the education levels, and the place of education policies in History of Turkish Education. They see the place of the history of the course in History of Turkish Education and the history of the concepts about education as unimportant.

\section{DISCUSSION AND PROPOSALS}

According to the results got by means of the findings in the research, there are some differences in description of History of Turkish Education concept stated by the participants. According to the another results in the research, almost all the prospective teachers attending to the research see the History of Turkish Education course to be in the undergraduate programs they follow as important. This finding shows us that the prospective teachers have positive attitude on the presence of the course.

These ideas which put forward the content dimension of History of Turkish Education course are also related to the value about the course. In attributing importance including affective qualifications, the subject of giving a value, curiosity and concern is also important in addition to other factors.

In order to increase the effectiveness level of the course, with the help of the data gained at the end of this research it is advised to use the visuals, films and etc. in the courses which prospective teachers see as important in History of Turkish Education course.

In addition to this, in the following studies, in the content we have prepared under 15 categories about History of Turkish Education, comparisons from different aspects can be done by taking ideas about the importance of each category.

According to the results got in the research, in the teacher training institutions, there are some optional courses (such as education and culture in Turkish thinkers) about the subjects the prospective teachers find as important in History of Turkish Education in limited number. These are not adequate. For this, the number of the optional courses the prospective teachers put on the top in terms of importance can be increased, and courses can be added to the departments where there are no optional courses about these subjects. 